\title{
IS THE CHILD VICTIM OF SEXUAL ABUSE TELLING THE TRUTH?
}

\author{
Kathleen Coulborn Faller, M.S.W., Ph.D. \\ Assistant Professor, School of Social Work, Co-director, University of Michigan Inter-disciplinary Project on \\ Child Abuse and Neglect, 1015 East Huron, Ann Arbor, MI 48109
}

\begin{abstract}
In order to adequately investigate an allegation of sexual abuse, professionals must both understand the motives of the victim, perpetrator, and victim's mother (in incest cases) to lie or tell the truth and possess the techniques for examining the child's story. Children almost never make up stories about being sexually abused. In fact victims are often revictimized in multiple ways for truthfully asserting they have been sexually abused. Perpetrators usually deny their abusive behavior. Mothers may also have reasons for not acknowledging the sexual abuse. Within this larger framework, the evaluator should systematically explore the allegation in order to assure the story is true. First, in examining the story, the evaluator looks for a detailed description of events surrounding the sexual abuse, explicit information about sexual behavior told from a child's viewpoint, and an emotional response consistent with their statement. Second, the evaluator buttresses the information with other data: (1) statements the child has made to other people about the sexual abuse; (2) sexual content in the child's play, picture drawing or story telling; (3) sexual behavior on the child's part; (4) sexual knowledge beyond what one would expect for the child's age; and (5) symptomatic behavior indicative of stress.
\end{abstract}

Résumé-L'idée de l'article est de fournir quelques directives aux travailleurs sociaux psychiatriques qui sont souvent amenés à faire une enquête dans un cas de soit-disant sévice sexuel. Il est grave de se tromper soit dans un sens soit dans un autre dans ces circonstances. Cependant les enfants n'inventent que rarement des récits fictifs tendant à faire croire qu'ils sont victimes d'abus sexuels. Il faut savoir aussi que les enfants sont souvent maltraités à nouveau par leur agresseur parce qu'ils ont dénoncé des sévices sexuels. En gènéral, les coupables nient leurs actes. Les mères des victimes craignent également que l'on croie les allégations de la victime, particulièrement dans les cas d'inceste père-fille. Souvent le sévice sexuel a pour origine des relations sexuelles déficientes entre le père et la mère de la victime. Parfois la mère favorise le rôle de partenaire substitutif que sa fille assume vis-à-vis du père. Celui qui doit èvaluer un cas doit donc explorer systèmatiquement la plainte afin de s'assurer que l'histoire est vraie. Il doit se faire fournir une description très détaillée des évènements entourant le sévice sexuel, se faire décrire en détail par la victime le comportement sexuel de l'assaillant, et doit en principe obtenir, associé à cette description, une réaction affective appropriée. L'enquêteur doit corroborer l'information ainsi obtenue à l'aide d'autres données: (1) les déclarations que l'enfant peut avoir faites à d'autres personnes concernant le sévice sexuel; (2) obtenir à travers les jeux de l'enfant, ses dessins ou les contes que ce dernier aime raconter, le contenu sexuel relatif aux évènements reels; (3) il doit évaluer le comportement sexuel de l'enfant lui-même; (4) les connaissances sexuelles de la victime dépassent en général celles qu'on attend d'un enfant de cet âge; (5) l'enquêteur devrait constater également un comportement symptomatique prouvant que l'enfant se trouve dans un état de grande tension émotive.

\section{INTRODUCTION}

OFTEN IN CASES OF SEXUAL ABUSE child welfare workers and mental health experts are asked whether or not a child's allegation of sexual mistreatment can be taken át face value or believed. If the child's story is trusted, the implications for action are far-reaching for both the child and the family. On the other hand, if the child is not believed and the allegation is true, the effect on the child will almost surely be devastating. Clearly, mental health profes-

This paper is based upon the author's clinical work and the study of over 120 cases of child sexual abuse as well as a review of selected literature. 
sionals need guidance in assessing children's allegation of sexual mistreatment. The purpose of this article is to provide such guidance.

This article addresses two facets of the investigation: the motives the various actors in sexually abusive situations have for being truthful or lying and a procedure for assessing an allegation of sexual abuse. It is necessary for the professional to understand not only the steps which need to be taken in an evaluation but also the family or interpersonal context of sexual abuse.

The article's main concern will be sexual abuse where there are female victims and male perpetrators (this configuration represents $75-90 \%$ of reported cases [1, 2] ) and on incestuous situations. Further, it will be especially concerned with the problem of substantiating sexual abuse of young children.

In this article incest is the term used for cases where there is a blood relationship between the victim and perpetrator. Sexual assault is the term for cases when victim and perpetrator are not blood relatives. The perpetrator in assault might be a stranger, a friend of the family, or the mother's boyfriend.

\section{WHO HAS THE MOST TO LOSE?}

\section{The Victim}

The evaluator needs to approach an allegation of sexual abuse with a clear understanding of who has a vested interest in lying and who in telling the truth. The victim places herself in considerable jeopardy as a result of telling the truth. She may be rejected by the perpetrator and ostracised by her family. She may be "punished" by placement in foster care or an institution. Her family may be torn apart, and she may see herself as responsible for its demise. She will have to tell the intimate details of her story to many people. Both the shame and guilt for having been involved in the sexual abuse, and the feeling of being responsible for any negative consequences to the family may inhibit her from telling. If the case goes to court, she may have to describe the intimate details of the abuse to strangers with the perpetrator facing her, and she may be subjected to harsh cross-examination by the perpetrator's attorney.

Frequently the perpetrator will threaten the victim with some of these consequences and urge her not to tell. Children in such a situation feel helpless in the face of a powerful adult. Because of the anticipated consequences, victims may keep the secret for months and sometimes years [3, 4]. Delay in the report of sexual abuse, therefore, is to be expected and ought not to be seen as a reason to question the veracity of the allegation. It is especially likely when there is a close personal relationship between the victim and the perpetrator. Nor is it uncommon for a child to reveal that she has been sexually abused, and then retract her story as she experiences the negative consequences of telling for herself and her family [5].

\section{The Perpetrator}

For his part, the perpetrator has everything to lose if the child's story is believed, and thus, in most cases, will deny he has sexually abused the child when indeed he has. He will likely face rejection by the immediate family and the extended family as well. Especially in fatherdaughter incest cases, divorce may ensue. In some instances, his employment may be in jeopardy. If the abuse is incest, he has reason to fear the juvenile court which may deprive him of his child, impose treatment, and intrude in other ways into the family. The perpetrator has even more cause to fear the criminal court, where he may be tried for criminal sexual conduct and sent to prison, or at least placed on probation. 
In addition to the practical consequences of admission are the psychological ones. Many perpetrators are so ashamed of their behavior that they cannot admit it. For some the shame is so great they will continue to deny in the face of overwhelming evidence. Furthermore, a substantial percentage of sexual abusers are to some extent character disordered; these men may lie. and lie convincingly and persistently over a period of months and even years. In their endeavor to persuade the decision maker of their innocence, they may enlist the help of family and friends.

\section{Mothers}

Mothers may also have a lot to lose if the victim's allegation is believed. particularly in father-daughter incest cases. First, to acknowledge the incest exists may be regarded by the mother as an indictment of her as a mother and a spouse. This may be so painful that "putting on blinders" is a more tolerable solution. Moreover, sexual abuse often develops when there are deficiencies in the sexual relationship between perpetrator (spouse or boyfriend) and mother. She may not want a sexual relationship with the perpetrator. Usually unconsciously, but sometimes consciously, she may facilitate the movement of the daughter into the incestuous relationship. Thus, even though she may not recognize them, there may be costs for the mother if the sexual abuse ends $[6,7]$.

The mother may also be facing more concrete and practical problems, for instance, financial dependency on the perpetrator. If she has to expel him, or if he goes to prison, she may have to seek other means of support. This can include going on Aid for Families with Dependent Children (AFDC), or seeking employment when she has never worked or has not worked in years.

Finally, should her spouse leave or be incarcerated, she will lose the emotional support he may have provided. To an outsider this may not seem much, but frequently he will be all the mother has, and she will not be able to imagine life without him. Many mothers of incest victims suffer from low self-esteem, and are very dependent upon their partners. They may choose their partners over their children if forced to choose one or the other.

Because of these dynamics, mothers of sex abuse victims often do not believe their daughters' allegations, ignore them when they are made, or try to deal with the problem without bringing in outside help. Alternatively, they may initially side with the child, but then switch their loyalties, and side with the perpetrator as they experience the practical consequences of the spouse's anger and/or loss of the spouse.

\section{EXAMINING THE CHILD'S STORY}

For the reasons stated above, we know that children do not make up stories asserting they have been sexually molested. It is not in their interests to do so. Young children do not have the sexual knowledge necessary to fabricate an allegation. Clinicians and researchers in the field of sexual abuse are in agreement that false allegations by children are extremely rare [7]. Further in those unusual instances where they do occur, there is usually some serious malfunction in the family.

In the past, some mental health professionals attributed children's allegations of incest to oedipal fantasies. Not only may it be easier to believe these assertions are fantasies than the truth, but there is support from Freud's writings and the psychoanalytic literature for this position $[8,9]$. Freud concluded when faced with accounts of incest by women diagnosed as hysterical that these recollections were fantasies [10]. Today many professionals believe that Freud was wrong in assuming categorically such allegations were fantasies [11, 12]. Moreover 
it is relatively easy to differentiate what is currently regarded as an oedipal fantasy from a report of sexual abuse.

Generally children preoccupied with oedipal fantasies will be between the ages of 3 and 6 . or the recollection itself is from that time in the child's life. The content of an oedipal fantasy consists of ideas of getting close to and being loved by the desired parent and excluding the other parent, rather than of any explicitly sexual material [13, 14]. For example, a 4-year-old girl asserted she was going to marry someone named "Raddy," whom she said looked like her daddy when he was 5 , and they were going to go to California so Raddy's mother would not be able to live with them.

Reports of sexual abuse can be differentiated from such fantasies by the victim's ability to give very specific details about what took place, assuming she is willing to discuss the incident(s). This includes details about the sexual abuse and surrounding events. In cases where the child is verbal, the best way to gather information is to ask about the last time the sexual abuse happened. Considerable detail can usually be elicited at least about the surrounding events, making the idiosyncratic nature of the incident quite clear. For example, a 6-year-old girl reported, "It was raining and I thought my daddy was asleep so I was playing in my brother's room where I'm not supposed to play. My daddy came in and I thought he would be mad at me, but he said he wouldn't be mad if I laid on the bed with him." The scenario related here is quite unique. Probes should be used if such detail is not automatically forthcoming. For instance, the interviewer might ask the victim what she was wearing, who else was at home, or what time of the day it was.

The child may be much more reticent about giving details of the sexual abuse than about recounting events surrounding the incident and this detail may require probing. To assure the veracity of the child's assertions, the interviewer should be looking for specific detail about the sexual behavior, a description which seems told from a child's viewpoint, and an emotional response consistent with the nature of the sexual abuse. For example, a $3^{1 / 2}$-year-old described her stepfather's digital penetration during self-masturbation as follows: "First he undressed me, then himself. He put two fingers in me, one in the front and said he was making white sugar and one in the back and said he was making brown sugar. He rubbed his bottom when he did it." When asked whether he rubbed himself in the front or the back, she pointed to the penis on an anatomically explicit doll. While relating this story, she was visibly upset. When she was finished, she said it was "gross" and it hurt.

Prior to discussing the sexual events, the interviewer needs to find out what names the child uses for private parts, and then use them in the questioning. This can be done by asking a trusted adult, or the child if no adult is available. If the child does not provide detail of sexual abuse spontaneously, sometimes it can be elicited by asking such questions as, "Did he touch your privates?" "Did he put his finger inside?" A less preferable alternative is for the evaluator to relate what she/he thinks happened and ask the child to respond "Yes" or "No" to each statement. It is desirable, however, to get a spontaneous statement of the events in order to avoid a situation where the evaluator might be putting words into the child's mouth. This is particularly important if the case is going to court.

A young child may be somewhat confused about the exact sequence of events, or may forget parts of the story at times, but these discrepancies should not call into question the veracity of the story. Further, young children may not be able to affix dates or exact times to incidents of abuse. However, they will usually be able to locate such acts in relation to significant events in their lives (e.g., on my birthday, the day it snowed, the nights when mommy goes out bowling, about supper time).

In gathering data about sexual abuse, the interviewer should try to find out whether the abuse hurt, "felt funny" or "felt good." Information should be gathered about what, if any. thing, the perpetrator said to the child about the sexual abuse: Was she threatened or told not to tell or bribed? The interviewer should probe for information about incidents of sexual 
abuse other than the most recent one by asking whether any abuse happened before the incident already described, and if so, how often and what took place. The victim should be asked if she knows whether the perpetrator ever did this kind of thing with anyone else. Thus, the goal of the interviewer is not only to elicit specific detail from the victim. but to also get a broader picture of the perpetrator's sexual activity with children. In incest cases, the interviewer should expect a history of sexual abuse over time, if the child is old enough. In contrast, cases of sexual assault are more likely to be single sexual encounters or intermittent ones.

\section{STRATEGIES FOR CORROBORATING THE CHILD'S STORY}

\section{The Child's Statement to Significant Others}

Sometimes knowledge about a sexual abuse incident is based solely upon physical evidence. However, more often cases of sexual abuse come to professional attention because the child has made a statement to someone, other than the evaluator, about the molestation. (In such a case there may be or may not be physical evidence.) The interviewer should talk directly with those persons to get all the information they have, and to assess the reliability of these reports.

Often a child will be candid with a parent or relative, but will be quite reticent with a professional. If this problem is anticipated, it may be possible to have those persons whom the child has told tape record the child's statements at home where the child feels less threatened. It is also a good practice to have such a person present during the interview, but some time will be needed alone with the child. In certain instances a child may feel less free to talk with a trusted adult because she does not want to upset that person, or because she does not want to make that person angry at the perpetrator.

In some cases children will refuse to talk during an evaluation, but later they will talk about the incident. Caretakers should be instructed that if this happens, they should tape record or write down the child's statements or telephone the evaluator and have the child repeat assertions over the phone. The professional should also tell the caretaker to take note of anything the child does subsequently which appears to be related to the abuse. For example, two sisters, ages 3 and 5, who had been sexually abused by their father, repeatedly simulated intercourse with one another after the evaluation. The 5-year-old had a bad dream in which she said, "My daddy pooped in my mouth." One type of sexual abuse in this case was fellatio.

\section{Using the Media of Play, Pictures, or Stories}

Certain behaviors and patterns which can be elicited in doll play, drawing, story telling, and other projective techniques, may be invaluable in corroborating an allegation of sexual abuse. With children who are reluctant to talk, information gathered in an indirect manner may be the only data that can be elicited in a formal evaluation. Depending upon the child's level of comfort, the evaluator may want to precede any direct questioning with attempts to elicit sexual content in play. Using these media to gather information is also less threatening to the child than direct questioning. The interviewer must be patient, and willing to spend two or three hours and sometimes several sessions gathering information.

What one looks for are sexual themes or content in the child's play, pictures, or stories. A useful process is as follows: The interviewer initially allows the child to use the medium in whatever way she wants. Sexual content may surface spontaneously. Whether it does or not, the evaluator will eventually want to structure the interaction so it focuses on the context in which the sexual abuse is thought to have taken place. For example, if a doll house and doll 
play are used, the interviewer will begin by allowing the child to play with the dolls in the doll house. Sexual concerns might emerge right away. The child may undress all the dolls and look between their legs or make the dolls engage in sexual acts. The worker will nevertheless want to structure the situation by focusing, for example, on a daddy doll and a little girl doll and ask, "What do daddies and little girls do together?" or "What does the daddy doll do with the little girl doll?" The child might then put the two dolls to bed together, one on top of the other. Such a pattern is likely to be repeated in various configurations. It is important then to ask whether the child engages in this behavior with her daddy, or ask what she does with her own daddy. A potential disadvantage of indirect methods of assessment is that the evaluator may elicit sexual themes in play but may not be able to tie these to the sexual abuse. By maneuvering the play context closer to the actual allegation, it is possible to make the link between general sexual content and the reported sexual abuse. This technique is particularly useful with young children whose language is limited. In such cases, the evaluator can rely on a combination of showing and telling.

Similar strategies can be employed with picture drawing and story telling. Picture drawing is appropriate for children of about 4 to 10. A 5-year-old evaluated by the author was asked to draw a picture of "anything." She drew a picture of her father with a penis, or as she said, "The peanuts." She was then asked to tell about "the peanuts," what it does and when she might have seen it. She then spoke of her father "trying to get bugs and maggots out of her vaginita (vagina) with his fingers while rubbing his peanuts against her butt." Making up stories in response to projective pictures is useful with children a little older. Sometimes a fruitful technique is to ask a child to draw a picture and then tell a story about it.

Anatomically explicit dolls can be useful aids in the assessment process. However, because most children have not had previous exposure to such dolls, they will elicit some unusual responses. Laughter, expressions of mild distaste, pulling on the private parts, and making the dolls go "potty" are normal reactions. Fear, anxiety, and vehement denial of knowledge about private parts are more worrisome patterns, and may be clues to sexual abuse.

In addition unstructured play with these dolls may elicit explicit sexual interactions from sexually abused children, while nonvictims might persist in having the dolls go "poop and pee." For example, one victim evaluated by the author put the daddy doll's penis in her mouth three times. This pattern was interspersed with fighting behavior between the mommy and daddy doll. A 9-year-old mildly retarded girl reenacted several times a scenario where a brother and sister were downstairs watching television. They then "smooched" repeatedly. Smooching involved sexual intercourse and concurrent kissing. She had been sexually abused by her 16-year-old brother over several years. As with doll house play, the interviewer can restructure the play context progressively closer to the alleged incident(s) of sexual abuse.

However, anatomically explicit dolls have additional utility. Because of their explicit nature, children can show what happened with the dolls rather than having to talk about it. They can do this by reenacting the scene of the sexual abuse. Alternatively, they can point to parts of the girl doll where they may have been touched, kissed, or penetrated, or to parts of the daddy doll they were induced to fondle or kiss, or which were put inside them.

We must also understand why certain children are not forthcoming about molestation, and, therefore, why indirect methods are necessary. First, the interviewer is likely to be relatively unknown to the child and usually less well known than the perpetrator. Children may admit the abuse to someone they trust-mother, an aunt, or a friend of the family- but be much less willing to make the revelation to a stranger. A related point is that in many cases even though the child has been molested by the perpetrator, the child may be attached to him, and will not want to cause him trouble. Alternatively, as noted earlier, the child may fear negative consequences for the family, or retribution by the perpetrator if she reveals the sexual abuse. 


\section{The Child's Knowledge of Sexual Matters}

Another important part of substantiating a sexual abuse allegation may be assessing the child's sexual knowledge. The data may be gathered in an interview, or by using information from other sources. Children who have been victims often are far more aware of sexual matters than most children of their age, or they may possess sexual information for which the family cannot explain a source. For example, a child of 4 who has been sexually abused may know a penis gets big and white juice comes out of it. In a recent evaluation, the author, using anatomically explicit dolls, asked a 3-year-old what daddies do with their "dinkies," (the child's word for penis). She replied, "Girls kiss it." While children may gain such knowledge from observation of sexual acts, it is not likely. If observation is the source of the victim's information, there is still cause to be concerned.

\section{Sexual Behavior}

Sexual behavior on the part of the child is another source of corroborative data. This is different from specific information elicited through play or questioning in an interview. It is generally more spontaneous and may occur in the context of the interview or in other settings. These sexual behaviors will vary with the age of the child. Generally, such evidence is more likely to be observed in younger children.

Excessive masturbation is one kind of behavior to look for in young children. While all children masturbate, molested children may do so to a marked degree. They may masturbate when they are upset, when they are questioned about the sexual abuse, or when they need comfort. They do so even though they are told not to. Some will injure their genitals in the course of repeated masturbation.

Young children who have been sexually molested may also initiate sexual encounters with others. In a day-care or hospital setting, they may sexually accost other children. In such a context, they may take on the role of the aggressor and victimize other children, or they may persist in their victim role. Sexually abused children may also attempt to elicit sexual responses from adults for whom they have some affection. We think they assume sexual interaction is the way adults and children who like one another show affection. Thus, a little girl may rub a male worker's penis, or wiggle her bottom on his lap. A boy who has been a victim of a female perpetrator may attempt to squeeze a nurse's breasts [15].

Latency-aged victims are often described as seductive and extremely concerned with their physical appearance. They may appear unusually feminine and coy. It is important for professionals to understand that victims have been socialized by perpetrators into a seductive pattern. Thus, whatever active role they play is a consequence of this socialization process. As these children grow older and reach early adolescence, they may become quite sexually active and be described as promis-cuous. The sexual encounters may be with peers or with older men. To illustrate, the mother of a 12-year-old girl complained that her daughter was very promiscuous, to the point that she had contracted gonorrhea three times. An evaluation uncovered that this child's promiscuity was preceded by sexual abuse by her father and stepfather. Some victims will also engage in prostitution as adolescents or as adults [16].

\section{Other Behavioral Indicators}

Additional supportive evidence is behavior which suggests a child's anxiety or troubled mental state. Behavioral symptoms stemming from this can be the result of sexual abuse.

With young children regression is frequently seen with the onset of sexual abuse. A child who previously was toilet trained may begin to wet the bed. A child who was easy to put to bed may become fearful of the dark, and refuse to go to bed without a trusted adult in the 
room. Nightmaring and nightwalking may also occur. For example, a 6-year-old evaluated by the author insisted on taking her "blankie" to school and had nightmares and wet the bed as a result of sexual abuse by her father.

A child's fear of the perpetrator may generalize to all men (assuming the perpetrator is a man). Sometimes this fear is more apparent with other men than with the perpetrator. Children also may appear depressed and become withdrawn. Victims who previously did well in school sometimes present with school problems. Often observers note a personality change in the victim which seems to coincide with the onset of the abuse. Thus, one victim's mother stated her daughter was "a motor mouth" before the molestation began, but now appears to be withdrawn and worried. In many cases, such symptoms as just described, occur after the abuse incident, diminish, and recur when another act of sexual abuse takes place.

Adolescents may present with acting out or self-destructive behavior. Thus, the adolescent victim may run away, be truant from school, be involved in fights and other aggression, have very hostile relations with her parents, often worse with mother than the father, steal and shoplift, and in general appear out of control. As a rule, the intensity of the adolescent victim's acting out is greater than the typical adolescent rebellion. Professionals may suggest institutional treatment for these victims because their deviance is so severe, frequently without comprehending the underlying cause. Self-destructive patterns found in adolescent victims are alcoholism, drug use and addiction, self-mutilation, and attempts at suicide, as well as successful suicides.

\section{CONCLUSION}

In order to evaluate an allegation of sexual abuse objectively, professionals must both be aware of the propensity of the different parties in the case to lie and have a grasp of how to go about assessing an allegation. If the evaluator takes a child's statements which may have been forthcoming in a formal interview, made to significant others but not to the professional, or made at one point and later retracted, and buttresses these with other information, a clear picture will evolve. Supplementary data may include sexual content in the child's play, picture drawing or story telling, sexual behavior on the part of the child, sexual knowledge beyond that expected for the child's age, and nonsexual behavioral indicators that the child is under stress. Obviously, the more supportive data the evaluator has, the more convinced he/ she will be, and the more persuasive the evaluator's report will be to others. However, the only information which should not be taken by itself as a sign there has been sexual abuse is the nonsexual behavioral indicators. Those indicators can also be a result of problems other than sexual ones.

\section{REFERENCES}

1. HERMAN, J. and HIRSCHMAN, L. Father-dauther incest. In: The Sexual Victimology of Youth, L. C. Schultz (Ed.), p. 98. Charles C. Thomas, Springfield, IL (1980).

2. KEMPE, C. H. Sexual abuse: Another hidden pediatric problem. Pediatrics 62:382-389 (1978).

3. HERMAN, J. and HIRSCHMAN, L. Lisa. In: The Sexual Victimology of Youth, L. C. Schultz (Ed.), pp. 109. Charles C. Thomas, Springfield, IL (1980).

4. RUSH, F. The Best Kept Secret: Sexual Abuse of Children. Prentice Hall, Englewood Cliffs, NJ (1980).

5. ZAPHIRIS, A. Incest: The Family with Two Known Victims. American Humane Association, Englewood, CO (1978).

6. JILES, D. Problems in the assissment of sexual abuse referrals. In: Sexual Abuse in Children. W. Holder (Ed.), pp. 58-64. American Humane Association, Englewood. CO (1980).

7. SUMMIT, R. and KRYSO, J. Sexual abuse of children: A clinical spectrum. American Journal of Orthopsychiatry 48:237-249 (1978). 
8. SGROI. S. Handbook of Cliniral Intervention in Child Sexual Abuse, pp. 39-80. Lexington Books, Lexington. MA $(1982)$

9. GOODWIN. J. SAND. D. and RADA. R. Incest hoax: False accusations, false denials. In: Sexual Abuse in Children. W. Holder (Ed.). pp. 37-45. American Humane Association. Englewood, CO (1978).

10. FREUD. S. The Sexual Enlightenment of Children. Collier Books. New York (1971).

11. RUSH. F. The Freudian cover-up. In: The Bext Kept Secret: Sexnal Amuse of Children. Prentice Hall. Englewood Cliffs. NJ (1980).

12. PETERS. J. Children who are victims of sexual assault and the psychology of offenders. American Journal of Psvchotherapy 30:398-421 (1976).

13. GOODWIN. J, SAND. D. and RADA, R. In: Sexual Abuse in Children, W. Holder (Ed.).

14. KLEINMAN. J. Interdisciplinary Project on Child Abuse and Neglect. Ann Arbor, MI. Personal communication.

15. FALLER. K. Indicatiors of child sexual abuse. In: Multidisciplinary Approaches to Child Abuse and Neglect. University of Michigan Interdisciplinary Project on Child Abuse and Neglect, Ann Arbor, Ml (1978).

16. CARLSON-LARSON, N. Family Sexual Abuse Training Course, University of Minnesota Medical School, Minneapolis, MN (1978). 